\title{
Understanding the New School Meal Standards ${ }^{1}$
}

\author{
Jenna Norris, Karla P. Shelnutt, and Gail P. A. Kauwell ${ }^{2}$
}

If you have school-age children, you may have heard that the 2012 school year brought major changes to the meals children eat at school. All meals provided through the School Breakfast and National School Lunch Programs now must be consistent with the USDA's Dietary Guidelines for Americans. The new standards are major components of the Healthy, Hunger-Free Kids Act, and they are the first major changes to school nutrition standards in 15 years (Food Resource and Access Center [FRAC], n.d.). The primary aim of the Healthy, Hunger-Free Kids Act is to improve child nutrition throughout the United States (USDA, 2013a). Most of the new requirements have already gone into effect, but the process is not complete until 2022 (USDA, 2012a).

The USDA lists the following major improvements (FRAC, n.d., School meal nutrition standards). The new standards will achieve the following:

- Increase the amount of fruits and vegetables served; emphasize whole-grain-rich foods; allow only lower fat and nonfat milk; limit calories; and reduce saturated fat and sodium.

- Require school lunch standards to be implemented in all schools for the 2012-2013 school year.

- Allow "Offer Versus Serve" fruit and vegetable options consistent with the Institute of Medicine recommendations. For more information about "Offer Versus Serve," see the section "Do the New Standards Have Any Disadvantages?"
- Improve cultural food options, such as allowing tofu to qualify as a meat/meat alternative.

The new school meal standards may be the first step in reducing childhood obesity and keeping children healthy at home and at school.

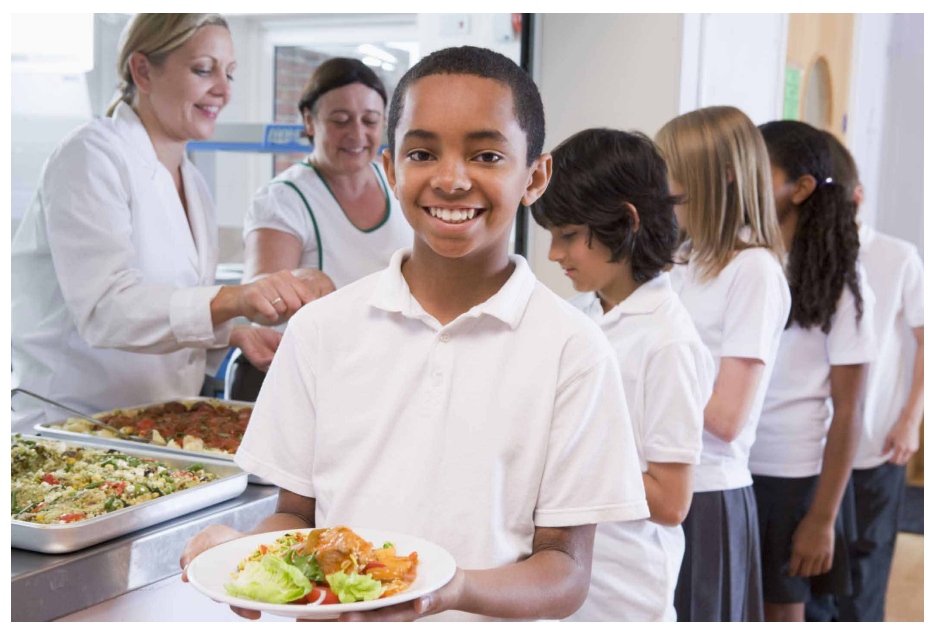

Figure 1. New school meal standards were introduced during the 2012-2013 school year. Credits: iStock

\section{What Are the New Standards?}

Under the new standards, school meals are intended to be "right sized," high in nutrients, and adequate in calories. In addition, they reflect an appropriate balance between food groups (USDA, n.d.).

1. This document is FCS80030, one of a series of the Department of Family, Youth and Community Sciences, UF/IFAS Extension. Original publication date: October 2013. Visit the EDIS website at http://edis.ifas.ufl.edu.

2. Jenna Norris, dietetic intern, Master of Science-Dietetic Internship Program, Food Science and Human Nutrition Department, Karla P. Shelnutt, assistant professor, Department of Family, Youth and Community Sciences, and Gail P. A. Kauwell, Food Science and Human Nutrition Department; UF/ IFAS Extension, Gainesville, FL 32611. 
The new standards set nutritional requirements for three different age groups: grades K-5, 6-8, and 9-12. Each age range has specific guidelines for breakfast and lunch. The School Breakfast Program sets requirements for fruits, grains, and milk, while the National School Lunch Program sets requirements for fruits, vegetables, grains, meat/meat alternatives (such as tofu and soy products), and milk (USDA, 2012b). The following tables (Table 1 and Table 2) list the number of servings of food from each food group that must be served in a week for each grade level. The amount listed in parentheses is the minimum amount that must be served every day.

Table 1. Amount of food that must be served each week by grade level for the School Breakfast Program (USDA, 2013b)

\begin{tabular}{|c|c|c|c|}
\hline & Grades K-5 & Grades 6-8 & Grades 9-12 \\
\hline Meal pattern & \multicolumn{3}{|c|}{$\begin{array}{l}\text { Amount of food per week (minimum per } \\
\text { day) }\end{array}$} \\
\hline Fruits (cups) & $5(1)$ & $5(1)$ & $5(1)$ \\
\hline Grains (ounces) & $7-10(1)$ & $8-10(1)$ & $9-10(1)$ \\
\hline Fluid milk (cups) & $5(1)$ & $5(1)$ & $5(1)$ \\
\hline \multicolumn{4}{|c|}{$\begin{array}{l}\text { Other specifications: Daily amount based on the average for a } \\
\text { 5-day week }\end{array}$} \\
\hline $\begin{array}{l}\text { Minimum and } \\
\text { maximum calorie } \\
\text { range allowed } \\
\text { (kcals) }\end{array}$ & $350-500$ & $400-550$ & $450-600$ \\
\hline $\begin{array}{l}\text { Saturated fat ( } \% \\
\text { of total calories) }\end{array}$ & $<10$ & $<10$ & $<10$ \\
\hline $\begin{array}{l}\text { Sodium } \\
\text { (milligrams) }\end{array}$ & $\leq 430$ & $\leq 470$ & $\leq 500$ \\
\hline Trans fat & \multicolumn{3}{|c|}{$\begin{array}{l}\text { Nutrition label or manufacturer specifications } \\
\text { must indicate zero grams of trans fat per } \\
\text { serving. }\end{array}$} \\
\hline
\end{tabular}

\section{New Versus Old Standards}

Changes to school meals are based on the latest nutritional science and are intended to provide one-fourth of students' daily calorie needs for breakfast and one-third for lunch (USDA, n.d.). The new standards reflect improvements to the weekly and daily requirements for fruits, vegetables, meat/meat alternatives, grains, milk, sodium, calories, and fat. Students will be served more nutritious foods such as fruits, vegetables, and whole grains and fewer foods containing sodium and fat. These changes are outlined on the following page (USDA, 2012c).
Table 2. Amount of food that must be served each week by grade level for the National School Lunch Program (USDA, 2013b)

\begin{tabular}{|c|c|c|c|}
\hline & Grades K-5 & Grades 6-8 & Grades 9-12 \\
\hline Meal pattern & \multicolumn{3}{|c|}{$\begin{array}{l}\text { Amount of food per week (minimum peI } \\
\text { day) }\end{array}$} \\
\hline Fruits (cups) & $21 / 2(1 / 2)$ & $21 / 2(1 / 2)$ & $5(1)$ \\
\hline Vegetables (cups) & $33 / 4(3 / 4)$ & $33 / 4(3 / 4)$ & $5(1)$ \\
\hline Dark green & $1 / 2$ & $1 / 2$ & $1 / 2$ \\
\hline Red/orange & $3 / 4$ & $3 / 4$ & $11 / 4$ \\
\hline $\begin{array}{l}\text { Beans and peas } \\
\text { (legumes) }\end{array}$ & $1 / 2$ & $1 / 2$ & $1 / 2$ \\
\hline Starchy & $1 / 2$ & $1 / 2$ & $1 / 2$ \\
\hline Other & $1 / 2$ & $1 / 2$ & $3 / 4$ \\
\hline $\begin{array}{l}\text { Additional vegetable } \\
\text { to reach total }\end{array}$ & 1 & 1 & $1 \frac{1}{2}$ \\
\hline Grains (ounces) & $8-9(1)$ & $8-10(1)$ & $10-12(2)$ \\
\hline $\begin{array}{l}\text { Meats/meat } \\
\text { alternatives (ounces) }\end{array}$ & $8-10(1)$ & $8-10(1)$ & $10-12(2)$ \\
\hline Fluid milk (cups) & $5(1)$ & $5(1)$ & $5(1)$ \\
\hline \multicolumn{4}{|c|}{$\begin{array}{l}\text { Other specifications: Daily amount based on the average for a } \\
\text { 5-day week }\end{array}$} \\
\hline $\begin{array}{l}\text { Minimum and } \\
\text { maximum calorie } \\
\text { range allowed } \\
\text { (kcals) }\end{array}$ & $550-650$ & $600-700$ & $750-850$ \\
\hline $\begin{array}{l}\text { Saturated fat (\% of } \\
\text { total calories) }\end{array}$ & $<10$ & $<10$ & $<10$ \\
\hline Sodium (milligrams) & $\leq 640$ & $\leq 710$ & $\leq 740$ \\
\hline Trans fat & \multicolumn{3}{|c|}{$\begin{array}{l}\text { Nutrition label or manufacturer } \\
\text { specifications must indicate zero grams of } \\
\text { trans fat per serving. }\end{array}$} \\
\hline
\end{tabular}

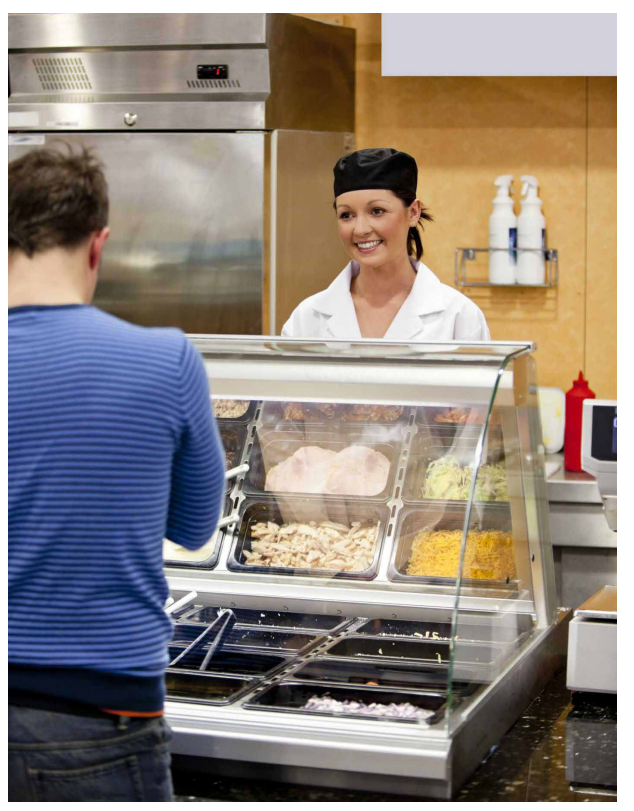

Figure 2. As part of the new school meal standards, students will be served more nutritious foods such as fruits, vegetables, and whole grains. Credits: Wavebreak Media 


\section{Fruits}

Perhaps the biggest change to fruit requirements is that under the old standards, fruits and vegetables were in the same category. Students were required to take a set amount of fruits or vegetables. Now they are required to take both fruits and vegetables. The only exception is the School Breakfast Program, in which students are allowed to substitute a vegetable in place of the fruit that is served.

\section{Vegetables}

According to the old standards, all vegetables were created equal; however, the new standards set requirements for including dark green, red/orange, beans/peas (legumes), and starchy vegetables. Variety is key here, because vegetables of a particular color contain specific nutrients, all of which are important for health. Eating a variety of different colored vegetables makes it easier to get the nutrients our bodies need.

\section{Meat/Meat Alternatives}

Under the old standards, students were required to be served a set amount of meat/meat alternative products (such as tofu and soy yogurt), regardless of their age. The new requirements reflect differences in the nutritional needs of children of different ages. This means that grades $\mathrm{K}-5$ are required to be served less meat/meat alternative products than grades 6-8 and grades 9-12.

\section{Grains}

Similar to meat/meat alternatives, the new standards have different weekly and daily grain requirements based on grade level. More importantly, the new standards require that at least half of the grains served must be whole grain rich. Beginning July 2014, all grains must be whole grain rich. In order to qualify as whole grain rich, a food must be at least 50\% whole grains (USDA, 2012b).

\section{Milk}

The amount of milk a student is required to take has not changed from the old standards, but the type of milk has changed. The old standards allowed a variety of fat contents and flavor was not restricted. Now, students must choose fat-free milk (unflavored or flavored), $1 \%$ low-fat (unflavored), or a milk alternative.

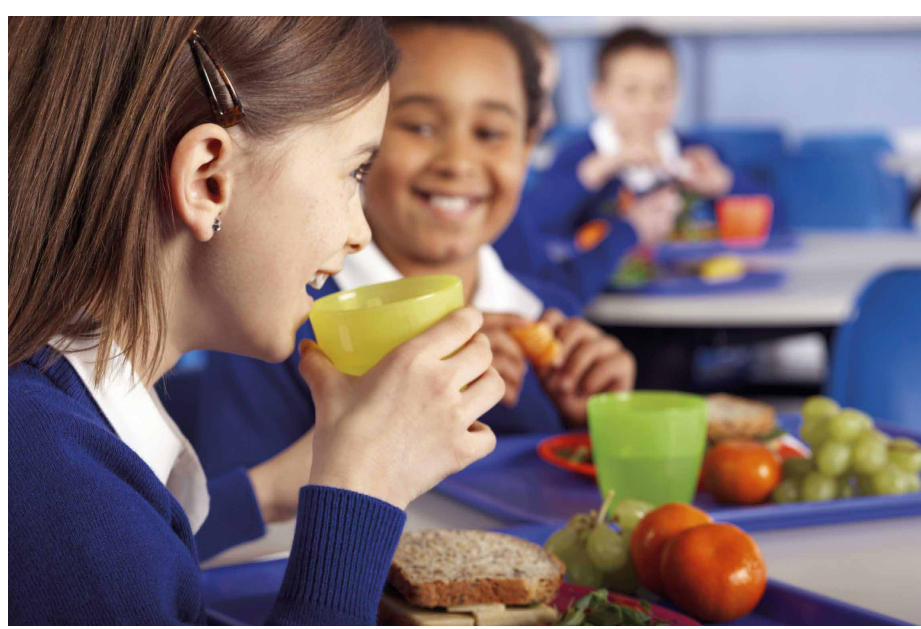

Figure 3. As part of the new school meal standards, students will be served more nutritious foods such as fruits, vegetables, and whole grains.

Credits: Wavebreak Media

\section{Sodium}

The old standards aimed to reduce the sodium content of school meals, but they did not set specific targets. The new standards set clear sodium restrictions for the three age groups. The level of sodium allowed in school meals will be reduced over the next ten years to achieve the target levels shown in Table 1 and Table 2.

\section{Calories}

The biggest concern about the new standards is whether children are getting enough calories to meet their energy needs. A comparison of the calorie contents of school meals before and after the introduction of the new standards indicates that the calorie levels are similar. Under the old standards, a school lunch had to meet a minimum calorie amount. For example, grades K-3 required at least 633 calories, and grades 4-12 required at least 785 calories. Schools had the option to serve grades 7-12 a minimum of 825 calories to better suit their energy needs (USDA, 2012d). The new standards require that the calorie amounts for each meal fall between a minimum and maximum number. By looking at the tables above, you can see that the required calorie amounts of meals under the old standards are similar to the calorie ranges set for meals under the new standards.

The new standards also do a better job of grouping students based on their nutritional needs. For example, the old standards required the same minimum calorie amount for grades $4-12$, but a 10 -year-old and an 18-year-old have very different energy needs. Under the new system, children with similar nutritional needs for their age are grouped together. 


\section{Fat}

The requirements for saturated fat have not changed; however, the new standards require that the product's nutrition label list the grams of trans fat as zero. The old standards set no limit on trans fat.

\section{Putting the New Standards to Practice}

The new standards are a bit easier to understand when you think about them in terms of a meal. Let's take a look at how a school lunch that fits the new requirements compares to one that meets the old requirements (USDA, 2012c).

Table 3. Old and new meal pattern comparison (USDA, 2012c)

\begin{tabular}{|l|l|}
\hline Old school lunch & New school lunch \\
\hline Bean and cheese burrito $(5.3 \mathrm{oz})$ & Submarine sandwich (1 oz \\
with mozzarella cheese (1 oz) & turkey, 1/2 oz low-fat cheese) on \\
Applesauce (1/4 cup) & whole-wheat roll \\
Orange juice (4 oz) & Low-fat refried beans (1/2 cup) \\
$2 \%$ milk (8 oz) & Jicama (1/4 cup) \\
& Green pepper strips (1/4 cup) \\
& Cantaloupe wedges, raw (1/2 \\
& cup) \\
& Skim milk (8 ounces) \\
& Mustard (9 grams) \\
& Reduced-fat mayonnaise (1 \\
& ounce) \\
& Low-fat ranch dip (1 ounce) \\
\hline
\end{tabular}

This comparison shows that the new school lunch offers more food and a larger variety of more nutritious foods.

\section{Do the New Standards Have Any Disadvantages?}

The new standards are intended to make America's children healthier, but not everybody is excited about them. Listed below are two of the major concerns.

\section{Hungry Children}

The calorie content of current school meals is about the same as it was before. However, many students, parents, and teachers have voiced concern that the new school meals, particularly in middle and high schools, are too small. Highly active students, such as athletes, do have higher energy needs than most students. Fortunately, schools have options available for these students. For example, these students are welcome to take second helpings of fruits and vegetables at lunch. In addition, a second carton of milk may be an option, depending on how close the student is to the calorie limit for his/her age group. Schools can structure after-school snack and supper programs to include service to athletes, or individual students and teams can supplement food provided through federal programs with items provided from home or other sources (USDA, n.d.).

\section{Waste}

Schools can use the "Offer Versus Serve" (OVS) technique to be more flexible with students' food choices. According to OVS, students must select at least three of the five food components offered to them (the five food components include meat/meat alternative, grains, fruits, vegetables, and milk). They are required to take at least $1 / 2$ cup of the fruit or vegetable component. A student may choose to mix different fruits and different vegetables (perhaps $1 / 4$ cup of a fruit and $1 / 4$ cup of a vegetable) to meet the minimum $1 / 2$ cup serving (USDA, n.d.). To get a better idea of how OVS works, take a look at Table 4 (Squires, 2012).

Table 4. How the "Offer Versus Serve" system works for school meals (Squires, 2012)

\begin{tabular}{|c|c|c|c|}
\hline What is served: & $\begin{array}{l}\text { What the } \\
\text { student takes: }\end{array}$ & $\begin{array}{l}\text { Does } \\
\text { the meal } \\
\text { follow } \\
\text { OVS? }\end{array}$ & Why? \\
\hline $\begin{array}{l}\text { Cheese pizza } \\
1 / 2 \text { cup tossed } \\
\text { salad } \\
1 / 2 \text { cup corn } \\
1 / 4 \text { cup } \\
\text { applesauce } \\
1 / 4 \text { cup pineapple } \\
1 \% \text { or fat-free } \\
\text { milk }\end{array}$ & $\begin{array}{l}\text { Cheese pizza } \\
2 \text { servings of } \\
\text { pineapple ( } 1 / 2 \\
\text { total) }\end{array}$ & Yes & $\begin{array}{l}\text { Three food } \\
\text { components } \\
\text { were selected: } \\
\text { meat/meat } \\
\text { alternative } \\
\text { (cheese), } \\
\text { grains (pizza } \\
\text { crust), and } \\
\text { fruit (1/2 cup } \\
\text { total). }\end{array}$ \\
\hline $\begin{array}{l}\text { Baked chicken } \\
1 / 2 \text { cup broccoli } \\
1 / 4 \text { cup grapes } \\
\text { Whole-wheat } \\
\text { roll } \\
1 \% \text { or fat-free } \\
\text { milk }\end{array}$ & $\begin{array}{l}\text { Baked chicken } \\
1 / 4 \text { cup grapes } \\
\text { Whole-wheat } \\
\text { roll } \\
1 \% \text { milk }\end{array}$ & No & $\begin{array}{l}\text { Even though } \\
\text { four food } \\
\text { components } \\
\text { are on the } \\
\text { plate, only } 1 / 4 \\
\text { cup of fruit } \\
\text { was selected. }\end{array}$ \\
\hline
\end{tabular}

Giving students options helps to eliminate situations in which students take too much food and throw it away. The best strategy to reduce food waste may simply be to engage and educate students about the new standards to increase acceptance. This might include taste tests of unfamiliar foods or using creative marketing/presentation techniques. Improving the way students view the food being served can make a big difference (USDA, n.d.). 


\section{Benefits of the New Standards}

Participating in the National School Lunch Program and the School Breakfast Program (especially under the new standards) reduces childhood hunger and improves children's diets. With the primary goal of preventing obesity, the new standards may be a big step in making our nation a healthier place to live. Listed below are the two primary benefits of the new meal standards.

\section{Reducing Childhood Hunger}

According to the USDA and the Census Bureau (2012e), an estimated 16.7 million children live in food-insecure households. This means that they have limited or no access to safe and nutritious foods. Therefore, providing food at school is necessary. The meals children receive in federally funded programs (such as the National School Lunch and School Breakfast Programs) are generally of higher nutritional quality than meals they receive elsewhere. According to the USDA (2012e), low-income school-age children who eat federally funded school breakfast have a better overall quality diet than those who eat breakfast elsewhere or skip breakfast. Students who eat meals at school are less likely to consume junk food and more likely to consume fruit, vegetables, and milk. Without the new standards in place, the $22.5 \%$ of U.S. children who live in food-insecure households would suffer (FRAC, 2010). Including healthier school meal options under the new standards reduces food insecurity and improves children's nutritional intake.

\section{Reducing Childhood Obesity}

Approximately one-third of America's school-age children are overweight or obese and at higher risk for diabetes, high blood pressure, depression, poor academic performance, behavior problems, and obesity before they reach adulthood. These risks increase for low-income children who do not participate in federally funded nutrition programs, because they have to rely on their family's limited resources. Evidence suggests that providing access to nutrient-rich foods at school reduces the risk of obesity. One study of U.S. students found that School Breakfast participation was associated with a significantly lower body mass index (BMI; an indicator of excess body fat). Providing nutrient-rich, healthy meal options under the new school meal standards might make the fight against childhood obesity a little easier. As the quality of school meals increase, so might participation (FRAC, 2010).

\section{Conclusion}

Change can be scary, but it doesn't have to be. Understanding exactly what is changing and why can help take some stress out of the situation. The new school meal standards may take some getting used to, but viewing them as improvements rather than changes may make the transition easier. Remember, the goal is to improve children's health, and when followed correctly, the new meal standards make school meals healthier and have the potential to improve children's health.

\section{References}

Food Resource and Access Center (FRAC). (n.d.). School meal nutrition standards. Retrieved from http://frac.org/ federal-foodnutrition-programs/school-breakfast-program/ school-meal-nutrition-standards

Food Resource and Access Center (FRAC). (2010). How improving federal nutrition program access and quality work together to reduce hunger and promote healthy eating. Retrieved from www.frac.org/pdf/CNR01_qualityandaccess.pdf

Squires, J. (2012). Offer vs. serve and the national school lunch program 2012-13 [PowerPoint slides]. North Carolina Child Nutrition Services. Retrieved from http://childnutrition.ncpublicschools.gov

USDA. (n.d.). The school day just got healthier. Retrieved from http://cspinet.org/new/pdf/new-school-meals-faq.pdf

USDA. (2012a). Implementation timeline for final rule.

Retrieved from www.fns.usda.gov/cnd/governance/legislation/implementation_timeline.pdf

USDA. (2012b). New meal pattern requirements and nutrition standards. Retrieved from www.fns.usda.gov/cnd/ governance/legislation/LAC_03-06-12.pdf

USDA. (2012c). Comparison of previous to new regulatory requirements. Retrieved from http://www.fns.usda.gov/ cnd/governance/legislation/comparison.pdf

USDA. (2012d). Nutrient analysis protocols: How to analyze menus for USDA's school meals programs. Washington, DC: USDA.

USDA. (2012e). Food security in the U.S. Retrieved from http://www.ers.usda.gov/topics/food-nutrition-assistance/ food-security-in-the-us/measurement.aspx 
USDA. (2013a). Healthy hunger-free kids act of 2010.

Retrieved from http://www.fns.usda.gov/cnd/governance/ legislation/cnr_2010.htm

USDA. (2013b). Nutrition standards for school meals.

Retrieved from http://www.fns.usda.gov/cnd/governance/

legislation/nutritionstandards.htm 